\title{
STRATEGI PENGOPTIMALAN PENCAPAIAN PROGRAM UPAYA PENINGKATAN PENDAPATAN KELUARGA SEJAHTERA
}

\author{
Bunga Chintia Utami \\ Universitas Lancang Kuning \\ Email : bungachintiautami@unilak.ac.id
}

\begin{abstract}
Abstrak
Kemiskinan di negara terbelakang dicirikan dengan pertumbuhan penduduk yang cepat. Di Indonesia, peran pemerintah dalam bidang kependudukan diserahkan pada Badan Kependudukan dan Keluarga Berencana Nasional (BKKBN). Salah satu program BKKBN adalah Upaya Peningkatan Pendapatan Keluarga Sejahtera (UPPKS). Sejak tahun 2010 hingga 2013 terjadi penurunan jumlah kelompok UPPKS. Berdasarkan permasalahan tersebut peneliti memfokuskan pada identifikasikan faktor kekuatan (strength), kelemahan (weakness), kesempatan (opportunity) maupun ancaman (threat) agar dapat mengoptimalkan hasil pencapaian Program UPPKS pada Direktorat. Tujuan penelitian adalah untuk melihat faktor kelemahan,kekuatan, ancaman dan peluang dan memilih strategi yang tepat untuk mengoptimalkan pencapaian program UPPKS. Metode yang digunakan adalah SWOT dan AHP. Hasil penelitian menunjukkan bahwa strategi terbaik berasal dari faktor kekuatan dan peluang (SO) yaitu (1) memanfaatkan ketersedian petunjuk teknis untuk pengembangan mitra kerja oleh daerah; (2) memaksimalkan pengggunaan data basis untuk bekerjasama dengan lembaga lain yang memiliki program pemberdayaan yang bersifat compilance; (3) memanfaatkan penggunaan website terintegrasi untuk menarik minat kerjasama sebagai bentuk pemanfaatan perkembangan teknologi dan informasi. Alternatif strategi tersebut diolah dengan menggunakan metode AHP sehingga ditemukan strategi prioritas untuk pengoptimalan pencapaian program UPPKS. Prioritas kebijakan yaitu memanfaatkan penggunaan website terintegrasi untuk menarik minat kerjasama sebagai bentuk pemanfaatan perkembangan teknologi dan informasi.
\end{abstract}

Kata Kunci: Keluarga Sejahtera SWOT, AHP, BKKBN

\begin{abstract}
Poverty in underdeveloped countries are characterized by rapid population growth. In Indonesia, the government's role in population to be submitted to the National Population and Family Planning (BKKBN). One of the programs is to Increase Revenue BKKBN Family's Welfare (UPPKS). From 2010 to 2013 a decrease in the number of groups UPPKS. Based on the problems identified factors researchers focused on strength (strength), weakness (weakness), chance (opportunity) and threats (threat) in order to optimize the achievement of program outcomes UPPKS the Directorate. The purpose of the study was to look at factors weaknesses, strengths, threats and opportunities and choosing the right strategy to optimize the achievement of program UPPKS. The method used is the SWOT and AHP. The results showed the best strategy is derived from the power factor and the opportunities (SO): (1) take advantage of the availability of technical guidance for the development of work by local partners; (2) maximizing the data base to cooperate with other agencies that have programs that are compilance empowerment; (3) utilizing the integrated use of the website to attract cooperation as a form of technological development and utilization of information. Utilizes the integrated use of the website to attract cooperation is priority.
\end{abstract}

Keywords: Keluarga Sejahtera(UPPKS), SWOT, AHP, BKKBN 


\section{PENDAHULUAN}

Kemiskinan negara terkebelakang ditandai dengan pertumbahan penduduk yang cepat. Jika kondisi menunjukkan ada peningkatan karena perbaikan tekhnologi dan peningkatan modal tetapi secara agregat akan tetap tidak terlihat karena pertambahan penduduk yang cepat. Sehingga perbaikan taraf hidup tidak akan terlihat(Jhingan, 2003). Meadow (1972) dalam bukunya "The Limit of Growth" menjelaskan hubungan variabel antar lingkungan, penduduk, produksi pertanian, produk industri, populasi, dan sumber daya alam terhadap kependudukan. Meadow menyatakan bahwa malapetaka seperti polusi, kelaparan, dan bencana alam adalah sesuatu yang tidak dapat dihindari. Sehingga yang dapat dilakukan adalah membatasi pertumbuhan penduduk serta mengelola lingkungan dengan baik. Kondisi pertumbuhan penduduk yang pesat juga terjadi di Indonesia. Indonesia adalah negara dengan jumlah penduduk keempat terbesar di dunia dengan kondisi laju pertumbuhan penduduk yang tinggi, dan persebaran penduduk yang tidak merata. Jumlah penduduk Indonesia sejak tahun 1971 hingga yang terus terjadi.

Beberapa penelitian juga menunjukkan bahwa kemiskinan erat kaitannya dengan jumlah anggota keluarga yang besar. World Bank dalam Jurnal Era Baru dalam Pengentasan Kemiskinan di Indonesia 2010 menjelaskan bahwa rumah tangga miskin memiliki jumlah anggota keluarga yang lebih besar. Jumlah rata-rata anggota rumah tangga miskin adalah 5,4 anggota dibandingkan jumlah anggota rumah tangga bukan miskin yaitu sebesar 4,3 anggota. Dengan demikian, jumlah anggota rumah tangga miskin 1 kali lebih banyak dari jumlah anggota rumah tangga bukan miskin. Rumah tangga dengan jumlah anggota 5 orang atau lebih memiliki kemungkinan menjadi miskin 2,7 kali lebih besar daripada rumah tangga dengan jumlah anggota yang lebih sedikit. Perbedaan dalam hal jumlah anggota keluarga umumnya disebabkan tingkat kelahiran yang lebih tinggi pada kalangan penduduk miskin. Jumlah rata-rata anak berusia di bawah 18 tahun pada rumah tangga miskin adalah 2,6, sementara pada rumah tangga tidak miskin hanya 1,6. Angka tersebut menunjukkan bahwa rumah tangga miskin jumlah anak yang dimiliki rata-rata lebih dari 2 orang.

Masalah kependudukan merupakan masalah bagi semua stakeholder khususnya pemerintah. Hal itu mengingat bahwa pemerintah sebagai penyelenggara negara dan diberi kekuasaan untuk mengatur aktifitas didalamnya untuk kepentingan orang banyak. Tugas terpenting pemerintah adalah mengatasi permasalahan sosial dan menciptakan situasi psikologis ideologis, sosial dan politik yang menguntungkan bagi pembangunan ekonomi (Myrdal, 1957). Pihak yang diserahi kewenangan dan tanggungjawab mengenai kependudukan di Indonesia adalah Badan Kependudukan dan Keluarga Berencana Nasional (BKKBN). Salah satu program yang dilakukan BKKBN adalah Upaya Peningkatan Pendapatan Keluarga Sejahtera (UPPKS). UPPKS merupakan program pembinaan ibu- ibu rumah tangga yang termasuk golongan Keluarga Pra Sejahtera (KPS) dan Keluarga Sejahtera I (KS I) agar mendapatkan penghasilan pribadi dengan memanfaatkan Sumber Daya Alam di sekitar lingkungan tempat tinggal. Program ini diharapkan memberikan penambahan pendapatan bagi keluarga serta mendorong terciptanya keluarga kecil dan sejahtera. Hal itu dapat dicapai melalui pembinaan kelompok dengan menerapkan 3 pokok pelaksanaan yaitu pengelolaan kelompok, pengelolaan administrasi dan keuangan kelompok dan pengelolaan usaha kelompok. Ketiga pokok pelaksanaan ini diharapkan mampu meningkatkan kemampuan berwirausaha hingga akhirnya mempengaruhi peningkatan hasil usaha dan pendapatan. Pada tahun 2010 hingga 2013 tercatat penurunan jumlah kelompok UPPKS.

Perkembangan desentralisasi menyebabkan perubahan kewenangan BKKBN yaitu tidak lagi bersifat terpusat. Setelah desentralisasi, BKKBN terdiri dari BKKBN pusat dan BKKBN perwakilan provinsi. BKKBN memiliki perwakilan di 33 provinsi sebagai Badan Kependudukan Dan Keluarga 
Berencana Daerah (BKKBD) Provinsi tetapi tidak mewajibkan adanya BKKBD kabupaten/kota sesuai dengan peraturan perundang-undangan yang membahas mengenai otonomi daerah. Hal itu seiring dengan yang diungkapkan oleh salah satu informan bahwa "Hal itu menyebabkan koordinasi yang lemah antara pusat dan daerah sebab daerah kabupaten/kota yang menentukan SKPD KB diperlukan atau tidak, berdiri sendiri atau tergabung dengan SKPD lainnya hingga menentukan program apa saja yang akan dilaksanakan"(Informan, 2014). Kondisi tersebut menyebabkan seperti ada bagian yang terputus dalam pelaksana program. Kondisi yang berbeda mengharuskan BKKBN Pusat mengoptimalkan implementasi dan kebijakan dilevel nasional sebagai bentuk usaha menanggapi perubahan situasi. Oleh karena itu, dalam pelaksaanaan program UPPKS perlu dilakukan penelitian ditingkat Direktorat karena program ini berasal dari tingkat pusat untuk dilaksanakan disemua daerah. Kebijakan yang baik ditingkat pusat menjadi acuan di daerah untuk diadopsi sebagai sebuah kebijakan. Berdasarkan beberapa temuan awal, peneliti tertarik untuk melihat lebih dalam mengenai pelaksanaan UPPKS pada BKKBN dan menemukan strategi apa yang paling baik untuk mengoptimalkan peran Direktorat Pemberdayaan Ekonomi Keluarga (Dir. PEK).

\section{METODE}

Metodologi yang dilakukan dalam penelitian ini menggunakan analisa SWOT dan AHP. Analisa SWOT digunakan untuk menganalisa faktor-faktor yang menjadi kekuatan, kelemahan, kekuatan, dan ancamaan pada program UPPKS. Hasil dari analisa SWOT akan memberikan alternatif-alternatif strategi kebijakan yang kemudian alternatif strategi kebijakan yang tersedia akan dipilih berdasarkan prioritas dengan menggunakan analisa AHP. Dalam penelitian ini, responden terbagi atas beberapa kelompok yaitu: (1) Pemerintah, terbagi atas BKKBN dan BPMPKB; (2)Akademisi pemerhati kebijakan kependudukan; (3) LSM/NGO yang bergerak dalam bidang yang sama (pemberdayaan masyarakat); (4)Masyarakat yang merupakan anggota kelompok UPPKS dan ketua kelompok asosiasi UPPKS.

Dalam memudahkan menganalisa faktor maka peneliti membagi faktor internal menjadi beberapa variabel yaitu Sumber Daya Manusia (SDM), proses, layanan/produk, biaya/anggaran, tempat/distribusi, promosi, dan respon pelayanan. Setiap variabel memiliki dimensi yang mendiskripsikan variabel. Pengelompokan variabel tersebut peneliti dapatkan dari penjabaran lingkunag dan eksternal yang dikemukakan Hunger dan Wheelen (1996), Soesilo (2002) dan Hildreth, dkk (2000). Variabel dan dimensi faktor internal dan variabel dan dimensi faktor eksternal dapat dilihat dari tabel berikut.

Metode SWOT akan memberikan gambaran variabel apa saja yang menjadi strategi pada faktor internal dan eksternal. Hasil dari matrik strategi internal dan eksternal kemudian diolah dengan menggunakan metode AHP. Pada pengelohan data peelitian ini, peneliti menggunakan program komputer (sofrware) untuk mengolah metode AHP. Program yang digunakan adalah Expert Choice edisi 2000. Dengan program ini maka peneliti dimudahkan untuk mengola hasil persepsi responden. Program ini menyediakan aplikasi menu untuk mendapatkan nilai inkonsistensi, sensitifitas, prioritas global dan prioritas lokal.

\section{HASIL DAN PEMBAHASAN}

\section{Analisis Faktor Kekuatan}

Dalam pelaksanaan program UPPKS, organisasi perlu mengetahui kekuatannya agar kekuatan yang ada dapat dimaksimalkan kegunaannya untuk memaksimalkan pencapaian program. Berdasarkan 
perhitungan dalam metode SWOT ditemukan 16 kekuatan Dir.PEK. Berdasarkan beberapa faktor kekuatan yang disebutkan sebelumnya maka dilakukan pemilihan faktor kekuatan yang berada diatas nilai rata-rata faktor kekuatan yaitu 11 faktor meliputi ketersediaan jumlah pegawai Dir.PEK cukup; koordinasi struktural Dir. PEK, kedudukan, tugas dan pelaksana UPPKS jelas, adanya petunjuk teknis yang dibuat oleh Dir. PEK, pengawasan melekat yang dilakukan oleh Kepala BKKBN, pengaturan visi program yang jelas dan terukur, ketersediaan data basis kelompok UPPKS yang dapat diakses dengan mudah, lokasi operasional pelaksana UPPKS tersebar merata, penggunaan media internet dalam bentuk website terintegrasi, adanya pelayanan terhadap kritik dan saran terkait UPPKS, adanya peraturan BKKBN yang mendukung dilaksanakannya UPPKS.

Kecukupan jumlah pegawai Dir.PEK. Kecukupan jumlah pegawai di Dir.PEK mendapatkan nilai 1,666667 Angka tersebut menunjukkan nilai variabel ini lebih tinggi dari nilai rata-rata 1,428571. Jumlah pegawai Direktorat Pemberdayaan Ekonomi adalah 18 orang. Temuan menarik adalah bahwa menurut akademisi bahwa "ketersediaan jumlah pegawai masih belum cukup karena tidak sebanding dengan jumlah tugas dan fungsinya terlebih berdasarkan penilaian jumlah pegawai setara dengan kementrian/lembaga"(Informan, 2014). Kementrian/lembaga ini rata-rata memiliki pegawai ditingkat direktorat sebanyak rata-rata jumlah pegawai direktorat 42 orang di Kementerian Dalam negeri(2011), 63 di Kementerian Komunikasi dan Informasi (2011) serta rata-rata pegawai di tingkat Direktorat pada Kementerian keuangan berjumlah 38 orang(2014). Namun sebagian besar informan menilai bahwa jumlah pegawai Dir PEK sudah cukup Hal itu jika dibandingkan dengan LSM sejenis yang mengelola pemberdayaan ekonomi masyarakat.

Koordinasi struktural Dir PEK. Koordinasi struktural Dir PEK dinilai sudah baik. Hal itu ditunjukkan dengan nilai 1,428571. Hal itu diperkuat dengan penilaian informan yang berasal dari Dir PEK yang menjelaskan bahwa koordinasi struktural dilakukan dalam berbagai bentuk. Koordinasi vertical atau koordinasi struktural mengkoordinasikan secara struktural dan terdapat hubungan hierarki. Hal ini juga dapat dikatakan koordinasi yang bersifat hierarkhi karena satu dengan lainnya berada pada satu garis komando ( line of command ). Misalnya koordinasi yang dilakukan oleh kepala direktorat terhadap para kepala sub direktorat yang berada dalam lingkungan direktoratnya. "Koordinasi disini sudah baik, setiap pegawai dilevel baawah bisa berkoordinasi dan memilikki akses yang cukup besar untuk berdiskusi langsung dengan pegawai lainnya yang setingkat maupun kepada atasan. Hal ini dapat dilakukan melalui diskusi biasa, rapat internal maupun koordinasi dalam bentuk lainnya"(Informan,2014).

Kedudukan, tugas dan Pelaksana UPPKS jelas. Poin ini mendapatkan nilai 1,833333 yang menunjukkan nilai variabel ini lebih tinggi dari nilai rata-rata 1,421568. Seperti dijelaskan sebelumnya, bahwa kedudukan Pelaksana UPPKS, dalam hal ini BKKBN melalui Dir. PEK memiliki kedudukan, tugas dan fungsi sesuai peraturan yang ada. "Kejelasan kedudukan, tugas dan pelaksaa yang tersebar pada 34 Provinsi memudahkan Dir PEK untuk mengkoordinasikan kebijakan secara merata dalam wilayah Indonesia"(Informan, 2014). Pada tingkat nasional pelaksanaan UPPKS menjadi tanggungjawab BKKBN, tingkat Provinsi menjadi tanggungjawab BKKBD Provinsi dan pada tingkat daerah di serahkan pada SKPD terkait KB.

Adanya petunjuk teknis yang dibuat oleh Dir. PEK. Poin ini mendapatkan nilai 1,333333 yang menunjukkan nilai variabel ini lebih tinggi dari nilai rata-rata 1,421568. Dalam buku Petunjuk Teknis UPPKS dijelaskan bahwa tujuan umum dari ketersediaan petunjuk teknis adalah untuk memberikan keseragaman petunjuk pelaksaanaan kepada para pengelola dan pelaksana dalam membina kelompok serta keterampilan bagi pengurus dalam mengelola kelompok. Tujuan khusus UPPKS adalah meningkatkan pengetahuan dan keterampilan pengelola dalam berorganisasi, menumbuhkan dinamika kelompok, menggali dan memanfaatkan sumber daya dan potensi setempat guna memajukan kelompok 
dan melihat kelompoknya secara utuh dan benar, termasuk kelemahan dan potensinya (Juknis UPPKS,2013).

Variabel selanjutnya adalah pengawasan yang dilakukan oleh Kepala BKKBN. Poin ini mendapatkan nilai 1,5 yang menunjukkan nilai variabel ini lebih tinggi dari nilai rata-rata 1,421568. Pengawasan yang dilakukan oleh Kepala BKKBN terhadap program UPPKS dinilai sudah baik. "Pengawasan dilakukan langsung oleh Kepala BKKBN kepada bawahannya dengan sistem pengawasan berjenjang"(Informan, 2014). Artinya pengawasan yang dilakukan Kepala BKKBN meliputi pengawasan terhadap Deputi dan deputi melakukan pengawasan terhadap direktorat serta direktorat mengawasai subdirektorat.

Visi program yang jelas dan terukur. Poin ini mendapatkan nilai 1,666667 yang menunjukkan nilai variabel ini lebih tinggi dari nilai rata-rata 1,421568. Visi BKKBN adalah Penduduk tumbuh seimbang 2015 dijabarkan dalam langkah strategis yang sinergi dalam revitalisasi program KB Seiring dengan visi BKKBN, visi Dir.PEK adalah " KPS dan KS 1 anggota kelompok UPPKS yang sejahtera dan mandiri dalam ber-KB" dengan misi yaitu "Mengembangkan Keberlangsungan kegiatan Kelompok UPPKS dalam mendukung terwujudnya keluarga kecil bahagia sejahtera". "Visi lembaga yang jelas dan terukur serta memiliki penjabaran dan keterkaitan dengan visi program menunjukkan bahwa pelaksana sudah memiliki pemahaman yang baik dalam pembuatan visi dan misi program"(Informan,2014).

Kekuatan lainnya adalah ketersediaan data basis kelompok UPPKS yang terakses dengan mudah. Website ini menyediakan data basis yang bisa diperbaharui oleh pihak terkait, baik oleh BKKBN maupun BPMPK Provinsi. Poin ini mendapatkan nilai 1,5 yang menunjukkan nilai variabel ini lebih tinggi dari nilai rata-rata 1,416666. "BKKBN melakukan sosialisasi melalui software yang menghubungkan antara BKKBN dengan BKKBD Provinsi sehingga berita dan informasi terintegrasi hingga ketingkat provinsi" (Informan,2014). Data UPPKS juga terintegrasi dalam kolom khusus yang disediakan dalam website BKKBN. Aplikasi website terintegrasi BKKBN dapat dilihat pada lampiran 7. Sehingga dalam pelaksanaannya ada keterkaitan yang sangat erat antara data basis dengan pemanfaatan website terintegrasi. "Data basis yang ada diperbaharui setiap tahunnya oleh BKKBN perwakilan daerah melalui penyuluh KB. Namun format data basis yang dibuat berupa profil kelompok masih dianggap memiliki beberapa keterbatasa" (Informan,2014). Jika aplikasi ini terintegrasi langsung dengan website kelompok UPPKS maka akan menjadi media sosialisasi yang baik. Data basis yang baik dapat menjadi titik fokus bagi BKKBN, BBKBN perwakilan provinsi maupun mitra kerja dalam menentukan bantuan apa yang akan diberikan untuk suatu kelompok pada suatu aderah. Hal itu karena data basis akan menjadi peta kondisi pelaksanaan UPPKS. Dalam website terintegrasi, aplikasi Keluarga Sejahtera menyediakan informasi mengenai Bina Ketahanan Balita, Bina Ketahanan Remaja, Bina Ketahanan Lansia, PLKB/IMP, Pusat Informasi Konseling Remaja dan Mitra Kerja serta Usaha Peningkatan Pendapatan Keluarga. Aplikasi UPPKS menyediakan data yang terintegrasi hingga ke provinsi yang meliputi data keanggotaan UPPKS, kesertaan ber-KB, Frekuensi akses modal, jenis usaha dan laporan progress. Namun sayangnya ketersediaan aplikasi ini belum disesuaikan memaksimalkan penggunaan. Hal itu terbukti data yang tersedia tidak terupdate secara keseluruhan. Sehingga akan terlihat data tahun lama atau data yang tidak sebenarnya. Tetapi dari BKKBN sendiri sudah memiliki keinginan memperbaiki dengan melakukan pemutihan data. Pemutihan data bertujuan untuk melakukan cross check data untuk mengetahui kebenaran dan kondisi saat ini.

Adanya pelayanan terhadap kritik dan saran terkait UPPKS. Poin ini mendapatkan nilai 1,666667 yang menunjukkan nilai variabel ini lebih tinggi dari nilai rata-rata 1,611111. Website ini juga menyediakan kolom kritik dan saran sehingga masyarakat maupun mitra kerja dapat memeberikan kritik dan saran secara mudah dan langsung." Namun layanan ini masih jarang digunakan oleh berbagai pihak 
untuk menyampaikan kritik dan saran terkait program" (Informan,2014). Adanya peraturan BKKBN yang mendukung dilaksanakannya UPPKS. Poin ini mendapatkan nilai 1,833333 yang menunjukkan nilai variabel ini lebih tinggi dari nilai rata-rata 1,611111. Ada beberapa aturan yang menjadi landasan hukum pelaksanaan UPPKS yaitu berupa peraturan kepala BKBBN.

\section{Analisis Faktor Kelemahan}

Berdasarkan metode SWOT yang digunakan menunjukkan 15 faktor kelemahan Dir.PEK. Berdasarkan beberapa faktor kelemahan yang disebutkan sebelumnya maka dilakukan pemilihan faktor kelemahan yang berada paling bawah nilai rata-rata faktor kelemahan tersebut yaitu 4 faktor meliputi tidak ada penelitian yang dilakukan Dir. PEK terkait UPPKS, rendahnya kesadaran dan pemanfaatan bonus demografi oleh pelaksana Dir.PEK, tidak ada ketersediaan biaya untuk pemasangan iklan layanan program UPPKS dan kemampuan mengakomodir mitra kerja masih rendah.

\section{Analisis Faktor Peluang}

Dalam program UPPKS yang menjadi kesempatan ada 10 faktor. Faktor peluang yang berada diatas nilai rata-rata faktor peluang tersebut yaitu 8 faktor meliputi semakin berkembangnya teknologi informasi untuk sarana sosialisasi, adanya program sejenis berupa pemberdayaan masyarakat untuk peningkatan ekonomi masyarakat, pemahaman masyarakat mengenai ukuran kesejahteraan sudah mulai meningkat, pernah kerjasama dengan lembaga keuangan seperti Bank, MOU dengan mitra kerja semakin meningkat kuantitasnya, pelatihan kewirausahaan untuk kelompok UPPKS dan PKB yang sudah cukup baik, jumlah peserta UPPKS yang banyak dan tersebar di 33 provinsi dan kualitas peserta UPPKS yang beberapa telah memenuhi standar pasar nasional.

\section{Analisis Faktor Ancaman}

Dalam metode SWOT, nilai yang berada dibawah rata-rata faktor eksternal maka dianggap sebagai ancaman. Berdasarkan perhitungan dengan metode SWOT terdapat 15 faktor ancaman pada pelaksanaan UPPKS. Faktor ancaman yang berada paling bawah nilai rata-rata faktor ancaman yaitu 10 faktor meliputi rendahnya daya serap lapangan kerja nonformal lainnya, penawaran peminjaman modal oleh mitra kerja dinilai masih rendah, pola pikir masyarakat mengenai wirausaha masih buruk, keterampilan masyarakat untuk berwirausaha masih rendah, masih sedikit pihak lain yang perhatian terhadap pelaksanaan UPPKS, tidak adanya tim pemeriksa keuangan terkait penggunaan dana UPPKS di daerah; kondisi politik di daerah kurang mendukung pelaksanaan UPPKS, masih sedikitnya peraturan daerah mengenai SKPD KB, pelatihan kewirausahaan pada pimpinan Dir PEK, belum ada pelatihan manajemen psikologis bagi $\mathrm{PKB}$, masih banyak minat kelompok yang belum terakomodir.

Perumusan strategi dilakukan berdasarkan faktor internal dan eksternal yang dimasukkan kedalam matriks interaksi IFAS-EFAS SWOT. Intraksi IFAS dan EFAS diperoleh dari hasil pembobotan pada faktor internal dan eksternal yang telah dilakukan sebelumnya. Karena dalam penelitian ini memiliki banyak bagian dalam setiap variabel maka yang ditampilkan dalam kolom matrik hanya beberapa bagian dari masing-masing kekuatan, kelemahan, peluang dan kesempatan yang menjadi perwakilan dari setiap faktor. Dari hasil pembobotan maka disusun prioritas strategi berdasarkan kombinasi strategi IFAS EFAS. Kombinasi strategi tertera dalam tabel1.

\section{Tabel 1. Urutan alternatif strategi SWOT}

\begin{tabular}{|lll|}
\hline Prioritas & Strategi & Bobot \\
\hline 1 & Strength - Opportunity (SO) & 3,791865957 \\
2 & Strength - Threath(ST) & 3,562171742 \\
3 & Weakness - Opportunity (WO) & 3,236987582 \\
4 & Weakness - Threath (WT) & 3,007293367 \\
\hline
\end{tabular}

Sumber: Telah diolah kembali 
Bobot diatas menunjukkan bahwa tugas Dir.PEK tidak terlalu berat. Hal itu berdasarkan kondisi kekuatan lebih besar dari kelemahan dan peluang lebih besar daripada ancaman. Pilihan strategi SO sebagai prioritas tertinggi bukan berarti strategi lain diabaikan tetapi jika ingin hasil yang maksimal maka strategi lain perlu dilaksanakan dengan sumber daya yang mendukung. Strategi SO merupakan strategi yang menggunakan kekuatan untuk memanfaatkan peluang. Berdasarkan analisa SWOT maka strategi SO yang ditawarkan diantaranya:

1. Memanfaatkan Juknis untuk memperluas kerjasama dengan mitra kerja oleh daerah

2. Meningkatkan kualitas data basis dan penggunaannya untuk memperluas kerjasama dengan lembaga lain yang memiliki program pemberdayaan yang bersifat compilance

3. Memanfaatkan penggunaan website terintegrasi untuk menarik minat kerjasama serta konektifitas dalam pelaksanaan program antar kelompok UPPKS serta antar kelompok UPPKS dan perangkat pelaksana.

Memanfaatkan juknis untuk memperluas kerjasama dengan mitra kerja oleh daerah merupakan strategi yang diambil untuk memanfaatkan faktor internal yaitu adanya juknis UPPKS untuk memperoleh peluang berupa kerjasama dengan mitrakerja. Juknis UPPKS sudah ada dan telah didokumentasikan dalam bentuk buku yang diberikan kepada seluruh pelaksanaan UPPKS ditingkat BKKBD Provinsi. Namun juknis yang ada saat ini masih keterbatasan isi yang hanya meliputi pengelolaan kelompok, pengelolaan administrasi dan keuangan dan pengelolaan usaha kelompok. Juknis belum membahas mengenai bagaimana pengelolaan agar memperoleh mitrakerja seperti tahapan yang dilakukan untuk memperoleh mitra kerja, bagaimana sistem pelaksanaan harus dibuat agar kelompok dapat memperoleh mitra kerja baik mitra kerja modal maupun mitra kerja pendampingan. Mitra kerja modal berkaitan dengan pemberian modal baik berupa pinjaman maupun bantuan. Sedangkan mitra kerja pendampingan berupa mitra kerja dalam usaha pembinaan kelompok baik dari akademisi universitas maupun LSM.

Strategi peningkatkan kualitas data basis dan penggunaannya untuk memperluas kerjasama dengan lembaga lain yang memiliki program pemberdayaan yang bersifat compilance merupakan strategi dengan menggunakan faktor internal ketersediaan data basis untuk memanfaatkan peluang kerjasama dengan pihak lain yang memiliki program pemberdayaan. Data basis dibuat oleh PKB dengan format yang ditentukan oleh BKKBN. Namun perlu adanya penambahan seperti kolom perkembangan aset, kebutuhan kelompok, perkembangan pemahaman $\mathrm{KB}$ anggota dan tingkat kesejahteraan anggota. Sehingga data basis yang tersedia lebih menggambarkan kondisi kelompok dan memudahkan pelaksana baik SKPD KB kabupaten/kota, BKKBD Provinsi dan BKKBN dalam membuat kebijakan selanjutnya. Ketersedian data basis yang lebih lengkap juga akan memudahkan mitrakerja untuk menentukan bantuan apa yang bisa diberikan untuk suatu kelompok, atau dengan keterbatasan bantuan yang diberikan maka akan terlihat kelompok mana yang sesuai dengan bantuan yang akan diberikan.

Strategi memanfaatkan penggunaan website terintegrasi untuk menarik minat kerjasama serta konektifitas dalam pelaksanaan program antar kelompok UPPKS serta antar kelompok UPPKS dan perangkat pelaksana adalah startegi yang dibuat untuk menggunakan faktor kekuatan berupa ketersediaan website terintegrasi untuk memanfaatkan peluang berupa minat kerjasama dan konektifitas pelaksana dengan pelaksana, kelompok dan mitra kerja serta kelompok dengan masyarakat umum. Website yang ada saat ini menjadi tanggung jawab pengelolaan dan biaya tanggungan BKKBN tetapi dalam pengelolaannya BKKBD provinsi dapat mengakses website untuk melakukan pembaharuan informasi pada bagian-bagian tertentu. Namun website terintegrasi tidak dapat dikelola oleh SKPD KB mengingat sistem kewenangan dan koordinasi pusat dan daerah. Sehingga data yang ada di lini lapangan harus dikumpulkan di BKKBD Provinsi agar bisa dicantumkan dalam website tersebut. Pembaharuan data tingkat provinsi masih dinilai cukup buruk karena beberapa data daerah misalnya data jumlah kelompok UPPKS perwilayah provinsi dan kabupaten tidak update serta beberapa link yang seharusnya 
menghubungkan pengguna dengan kelompok UPPKS tidak bisa diakses. Kelompok UPPKS yang ditampilkan juga hanya sebatas kelompok yang unggul sedangkan kelompok yang belum unggul tidak ditampilkan. Sehingg apengguna website khususnya mitra kerja belum bisa mengakses dengan mudah kebutuhan kelompok UPPKS karena tidak bisa mengakses langsung profil kelompok UPPKS. Kondisi yang terjadi ini dikarenakan masih terbatasnya sumber daya BKKBD Provinsi dalam menginput data yang sangat banyak terkait profil kelompok dan penilaian bahwa kelompok yang belum unggul tidak terlalu urgen untuk dimasukkan dalam tampilan kelompok UPPKS di website karena dapat menambah beban program/software jika data terlalu banyak (Informan,2014).

Pemanfaatan website terintegrasi diharapkan akan mampu memberikan kemudahan bagi pelaksana seperti BKKBN dalam mengamati pelaksanaan program UPPKS di daerah, menudahkan mitra kerja untuk melihat kondisi UPPKS dan kebutuhan UPPKS sehingga memudahkan mitra kerja untuk menentukan jenis kerjasama dan skala kerjasama yang akan diberikan untuk kelompok UPPKS bahkan untuk skala terkecil misalnya suatu LSM mampu memberikan pembinaan untuk untuk 10 kelompok terpilih berdasarkan data yang diaksesnya dari website terintegritas, memudahkan kelompok UPPKS dalam mempromosikan usahanya jika website terintegrasi juga menampilkan profil kelompok berserta usahanya.

Pada hakekatnya, meskipun strategi SO merupakan alternatif strategi terbaik yang memiliki nilai pembobotan tertinggi tetapi belum tentu strategi tersebut dapat dilaksanakan. Sehingga perlu dilakukan skala prioritas. Hal itu dikarenakan dalam pelaksanaan kebijakan pasti mengahadapi berbagai kendala. Oleh karena itu perlu dilakukan analisa dengan menggunakan Analytical Hirarchi Process (AHP). AHP adalah Pemilihan tahapan strategi perumusan skala prioritas kepentingan /urgensi terhadap skenario yang mungkin terjadi dan terhadap pencapaian sasaran menurut versi responden tersebut. AHP dapat melakukan pemilihan berbagai kriteria skenario, sasaran, strategi dengan mengumpulkan persepsi expert. Prosesnya dilakukan melalui pengisian kuisioner AHP.

Analisa AHP

Berdasarkan strategi yang dihasilkan dari analisa SWOT tersebut maka peneliti mengembakannya kedalam perumusan strategi dengan menggunakan metode AHP. Pada level strategi, peneliti hanya memasukkan alternatif strategi kebijakan dari strategi terpilih yaitu SO. Dalam AHP, penyusunan hirarki adalah salah satu proses penting. Hirarki menyusun permasalahan yang kompleks ke dalam bentuk yang sederhana. Penelitian ini menyusun kedalam 3 hirarki yaitu tujuan, skenario yang mungkin terjadi, dan alternatif strategi yang diperoleh dari analisa swot. Hirarki dapat dilihat pada gambar 3 dibawah ini.

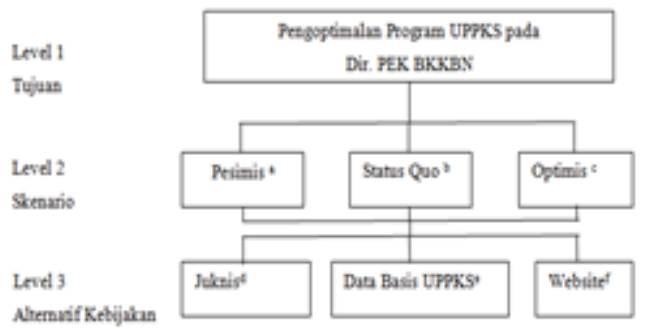

Sumber: Telah diolah kembali

Gambar 3. Hirarki penentuan prioritas strategi dalam Pengoptimalan Pencapaian Hasil UPPKS melalui peran Dir. PEK

Berdasarkan hasil perhitungan dan pengolahan data dari responden diatas maka hasil tersebut diolah melalui program Expert Choice release 8 dapat dilihat dari Gambar 4 dibawah ini. 


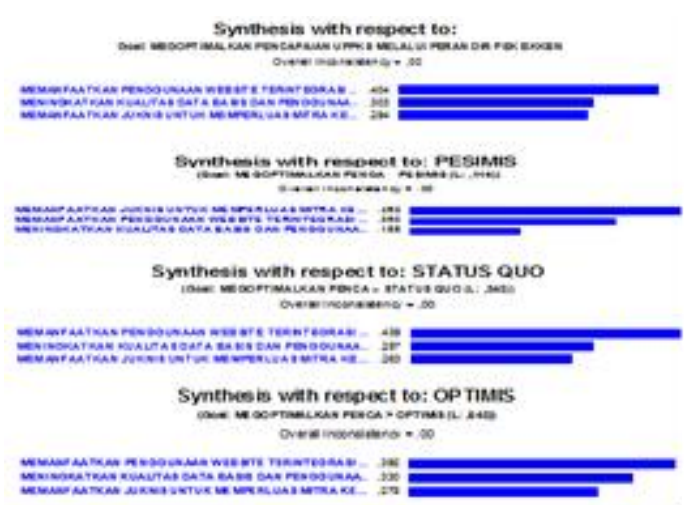

Sumber: Telah diolah kembali

\section{Gambar 4. Hasil Pengolahan AHP}

Pada level 3 mengenai alternatif kebijakan terlihat bahwa yang memiliki nilai tertinggi adalah alternatif strategi Memanfaatkan penggunaan website terintegrasi untuk menarik minat kerjasama sebagai bentuk pemanfaatan perkembangan teknologi dan informasi adalah strategi kebijakan yang memiliki nilai tertinggi. Kemudian strategi selanjutnya adalah Memaksimalkan pengggunaa data basis untuk bekerjasama dengan lembaga lain yang memiliki program pemberdayaan yang bersifat compilance dan strategi pilihan terakhir adalah Memanfaatkan ketersedian Juknis untuk pengembangan mitra kerja oleh daerah.

Pada level 2, saat skenario pesimis terjadi maka prioritas alternatif kebijakan yang direkomendasikan adalah memanfaatkan juknis untuk memperluas mitra kerja di daerah, pada skenario status quo kebijakan yang direkomendasikan adalah Memanfaatkan penggunaan website terintegrasi untuk menarik minat kerjasama sebagai bentuk pemanfaatan perkembangan teknologi dan informasi. Hal yang sama juga direkomendasikan untuk kondisi optimis yaitu Memanfaatkan penggunaan website terintegrasi untuk menarik minat kerjasama sebagai bentuk pemanfaatan perkembangan teknologi dan informasi.

Website terintegrasi seharusnya berisi data UPPKS dan perkembangannya. Website harus didukung dengan ketersediaan data basis yang memadai sehingga antara data basis dan website terintegrasi adalah dua hal yang berkaitan. Website merupakan penghubung (konektifitas) antara: (1) kelompok UPPKS dengan pemerintah seperti BKKBN, BKKBN perwakilan provinsi dan SKPD KB daerah; (2) kelompok UPPKS dengan mitra kerja sehingga mitra kerja seperti Bank dan akademisi/universitas lebih dimudahkan dalam mengenali kelompok yang akan diberikan bantuan baik berupa pinjaman maupun bantuan pendampingan; (3) kelompok UPPKS dengan kelompok UPPKS lainnya dapat berinteraksi atau bertukar informasi dalam meningkatkan hasil usaha. Hal ini dapat dilakukan jika website menyediakan data basis yang lengkap dan mudah diakses oleh semua pihak.

Data basis saat ini hanya menampilkan beberapa informasi umum seperti waktu berdirinya kelompok, alamat, frekuensi pertemuan, nama anggota, kualifikasi pendidikan, tingkat kesejahteraan menurut tahapan keluarga, jenis udaha, jumlah modal, sumber modal, tindakan promosi, jangkauan pemasaran, kelengkapan pembukuan/administrasi, ketersediaan ATTG, dan nama petugas pembina/pendamping. Beberapa kelemahan dari data basis yang ada diantaranya adalah pengisian data tidak lengkap, tidak ada mencantumkan perkembangan omset, tidak ada menjelaskan kebutuhan dan kendala kelompok serta perkembangan tingkat kesejahteraan anggota kelompok. Seharusnya data basis dilakukan revisi untuk memperbaiki format yang ada sebelumnya. Revisi format dilakukan untuk melengkapi data perkembangan yang belum dicantumkan. 
Petunjuk teknis berisi pendahuluan, pokok-pokok pelaksanaan, dan mekanisme pengelolaan dan pengembangan kelompok UPPKS. Pendahuluan membahas mengenai latar belakang, tujuan, ruang lingkup, pengertian, landasan hukum UPPKS. Pokok-pokok pelaksanaan membahas beberapa hal seperti (1) pengelolaan kelompok yang terdiri dari identifikasi pembentukan kelompok, pemanfaatan sumberdaya dan dana; (2) pengelolaan administrasi keuangan meliputi buku indeks, buku kegiatan, buku kas harian, buku simpanan, sumbangan, pinjaman, angsuran, buku kas dan buku bank, buku tamu dan buku ekspedisi; (3) pengelolaan usaha kelompok. Sedangkan mekanisme pengelolaan dan pengembangan kelompok UPPKS terdiri dari mekanisme pengelolaan kelompok, mekanisme pengelolaan administrasi keuangan dan mekanisme pengelolaan usaha kelompok. Juknis yang jelas dan lengkap dalam membahas tahap pelaksanaan program UPPKS akan memudahkan pelaksana ditingkat daerah untuk mengaplikasikan dan mengembangkan program. Kejelasan tahapan pelaksanaan akan memudahkan kerjasama dengan mitra kerja. Hal itu dikarenakan baik BKKBN perwakilan provinsi maupun mitra kerja akan mengetahui tahapan apa saja yang harus dilakukan untuk melakukan kerjasama, dan dalam bentuk seperti apa kerjasama akan dilakukan. Beberapa kelemahan juknis diantaranya adalah tidak membahas lebih detail mengenai produksi, akses modal, pemasaran, dan sistem pembagaian hasil usaha. Oleh karena itu maka Dir. PEK perlu melakukan evaluasi juknis dan merevisi kembali buku juknis yang sudah diterbutkan sejak tahun 2010 tersebut. Revisi yang dilakukan berapa penambahan beberapa item yang dianggap penting seperti bagaimana cara produksi yang baik, bagaimana tahapan untuk memperoleh akses modal, bagaimana cara melakukan pemasaran yang benar, dan bagaimana sistem pembagaian hasil usaha yag dapat meningkatkan semangat kerja anggota.

\section{KESIMPULAN}

Berdasarkan pembobotan SWOT ditemukan strategi yang paling tinggi nilainnya terletak pada pembobotan SO. Strategi SO meliputi: (1) memanfaatkan ketersedian Juknis untuk pengembangan mitra kerja oleh daerah; (2) memaksimalkan pengggunaa data basis untuk bekerjasama dengan lembaga lain yang memiliki program pemberdayaan yang bersifat compilance; (3) memanfaatkan penggunaan website terintegrasi untuk menarik minat kerjasama sebagai bentuk pemanfaatan perkembangan teknologi dan informasi. Ketiga strategi tersebut diolah menggunakan AHP dan menghasilkan rekomendasi kebijakan. Pada saat kondisi masa depan menunjukkan mengalami perubahan kondisi yang lebih buruk pada saat ini maka prioritas alternatif kebijakan yang direkomendasikan adalah memanfaatkan juknis untuk memperluas mitra kerja di daerah. Sedangkan pada skenario status quo dan optimis kebijakan yang direkomendasikan adalah memanfaatkan penggunaan website terintegrasi untuk menarik minat kerjasama sebagai bentuk pemanfaatan perkembangan teknologi dan informasi.

Berdasarkan temuan tersebut peneliti memberikan saran terkait website terintegrasi, data basis dan juknis. Dalam peningkatan pencapaian hasil program UPPKS maka Dir.PEK harus Memanfaatkan penggunaan website terintegrasi untuk menarik minat kerjasama sebagai bentuk pemanfaatan perkembangan teknologi dan informasi. Penggunaan website yang telah terintegrasi kedaerah bisa dimaksimalkan dengan menambahkan beberapa item seperti perkembangan omset kelompok, lokasi dan layanan timbal balik yang bisa diakses oleh kelompok. Hal ini bertujuan untuk memanfaatkan perkembangan teknologi dan sebagai salah satu bentuk layanan BKKBN sebagai pelaksana pusat dari program UPPKS serta sebagai penarik bagi mitra kerja (Bank dan Lembaga keuangan lainnya untuk berpartisipasi). Website yang terintegrasi juga sebaiknya diiringi dan peningkatan kemampuan kelompok dalam penggunaannya. Sehingga tidak hanya SKPD daerah saja yang memiliki akses kepada website 
tersebut tetapi sampai ke kelompok UPPKS sebagai target dari program tersebut.

\section{DAFTAR PUSTAKA}

[1]. Agustino, Leo. (2006). Dasar-Dasar Kebijakan Publik..Alfabeta. Bandung

[2]. Agus Widarjono. (1999) . Penduduk dan Pertumbuhan Ekonomi di Indonesia : Analisis Kausalitas , Jurnal Ekonomi Pembangunan, Vol 4 No 2 Tahun 1999.

[3]. Arief, Sritua. (1993). Metode Penelitian Ekonomi. UI-Press. Jakarta

[4]. Asri,Dwi Asmarani. (2010). Strategi Kebijakan Pembangunan Daerah Kabupaten Klaten : Pendekatan Analisis SWOT dan AHP. Tesis. Magister Perencanaan dan Kebijakan Publik FE UI

[5]. Basri, Faisal. (2002). Perekonomian Indonesia. Erlangga. Jakarta

[6]. Boediono. (1985) . Teori Pertumbuhan Ekonomi. BPFE. Yogyakarta.

[7]. Badan Koordinasi Keluarga Berencana Nasional.( 2002). Kependudukan KB dan KS. Jakarta. (2001) Visi dan Misi Program KB Nasioanl. Jakarta

[6]. Brodjonegoro, Bambang. (1992). AHP (The Analytic Hirarchi Process). Pusat Antar University Studi Ekonomi Universitas Indonesia. Jakarta

[7]. Danim, Sudarwan. (2000). Penelitian Kebijakan. Bumi Aksar. Jakarta

[8]. Dumairy, 1997. Perekonomian Indonesia. Jakarta : Penerbit Erlangga.

[9]. Dunn, William. (2003). Pengantar Analisa Kebijakan Publik Edisi Kedua. Gadjah Mada University Press. Yogyakarta

[10].Elfidri, Rasmita. (2006). Kualitas manusia Indonesia. Visi Media. Jakarta

[11].Glaster,. dan Falshaw. (1999). Strategic planning: Still going strong? Long Range Planning. Volume $32(1)$

[12].Grindlee. (1980) . Politics and Policy Implementation in the Third World. Princeton University Press. New Jersey

[13].Hunger, David dkk. (1996) . Manajemen Strategis. Andi. Yogyakarta

[14].Indiahono, Dwiyanto.().Kebijakan Publik: Berbasis Dynamic policy Analisys. Gava Media. Yogyakarta 
[15].Jhingan. (2003). Ekonomi Pembangunan dan Perencanaan. Raja Grafindo Persada. Jakarta

[16].Hardiani, Junaidi . (2009). Dasar-Dasar Teori Ekonomi Kependudukan. Hamada Prima

[17].Hutasoit, Donal. (2005). Strategi Pengelolaan Taman Nasional Kerinci Seblat dalam rangka mengurangi laju kerusakana hutan, Suatu pendekatan SWOT Dan AHP. Tesis. MPKP FE UI

[18].KartonoWirosuhardjo. (1981). Kebijakan Kependudukan ( Dasar-Dasar Demografi). LDFE UI. Jakarta

[19].Keban,Yeremias T. (2008) . "Enam Dimensi Strategis Administrasi Publik Konsep, Teori Dan Isu”. Gava Media. Yogyakarta.

[20].Nitisastro, Widjojo. (1970) . Population trends in Indonesia. Cornell University Press. New York

[21].Nugroho, Riant. (2007). Analisis Kebijakan. PT Elex Media Komputindo. Jakarta

(2008) . Publik Policy. Gramedia. Jakarta

[22].Mankiw. (2006). Makroekonomi (Fitria Liza dan Imam Nurmawan, Penerjemah). Edisi Keenam. Penerbit Erlangga. Jakarta.

[23].Parawansa, Khofifah Indar. (2000). Pokok-Pokok Pikiran Kebijakan dan Strategi Era Baru Gerakan KB Nasional. LDFE UI-Warta Demografi Tahun ke-30, N0.1, 2000. Jakarta

[24].Parsons, Wayne. (2008). Publik Policy: Pengantar teori dan Praktik Analisis Kebijakan. Kencana. Jakarta

[25].Saaty, T.L. (1998) . Multicriteria Decision Making : The Analytic Hirearchy Process. Nijhoff Publishing. USA

[26].Subarsono. (2008). Analisa Kebijakan Publik Konsep Teori dan Aplikasi. Pustaka Pelajar. Yogyakarta

[27].Sukirno, Sadono, 2006. Ekonomi Pembangunan (Proses, Masalah, dan Dasar Kebijaksanaan). Jakarta : Fakultas Ekonomi Universitas Indonesia.

[28].Soesilo, Nining. (2002). Reformasi Pembangunan Perlu Pendekatan Manajemen Strategis. Magister Perencanaan dan Kebijakan Publik Fakultas Ekonomi Universitas Indonesia. Jakarta

[29].Solihin,Dadang. (2006) . Ekonomi Pembangunan: Overview Indonesia Masa Krisis1998. Artifa Duta Prakarsa. Jakarta

[30].Todaro, Micheal P. dan Smith Stephen C. (2004). Pembangunan Ekonomi. Jilid 1 (Terjemahan). Edisi kesembilan. Erlangga. Jakarta 
[31].UNDP, United Nations Development Programme. 2013. Human Development Report 2013 the rise of the south : Human progress in a Diverse world.

[32].Wibawa, Samudra. (1994). Evaluasi Kebijakan Publik. Raja Grafindo Persada. Jakarta

[33].Winarno, Budi. (2003). Kebijakan Publik:Teori dan Proses. Media Pressindo. Yogyakarta

[34].Zainal Arifin. (2002). Strategi Kebijakan Fasilitas Perencanaan Pembangunan daerah Direktorat Jendral Bina Pembangunan Daerah Pada era Otonomi Daerah:Suatu pendekatan Analisa SWOT dan AHP. Tesis. Magister Perencanaan dan Kebijakan Publik FE UI

[35].Becker, Gary S. (1976). An Economic Analysis of Fertility . Jurnal : The Economic Approach to Human Behaviour. The University of Chicago

[36].Becker, Gary S. (1981). A Treatise on the Family. Harvard University Press. England.

[37].Bongaarts, John. (1994) . Population Policyoption in the Develophing World. Science 263.

[38].Li, Shaomin. (1989). China's Population Policy: A model of Constant Stream of Births. Office of Population Research. Princeton

[39].Kirk,Dudley. (1996). Demographic Transition Theory. Population Studies vol 50

[40].Kahraman, dkk. (2007). Prioritization of e-Government strategies using a SWOT-AHP analysis: the case of Turkey. European Journal of Information Systems 16.

[41].Helms, Marilyn M,dkk. (2010) . Exploring SWOT analysis - where are we now?: A review of academic research from the last decade. Journal of Strategy and Management3.

[42].Radifan, Muhammad. (2010). Analisis Faktor-Faktor Yang Mempengaruhi Fertilitas Di Indonesia

[43].Taleai, Mohammad,dkk. (2009). Surveying general prospects and challenges of GIS implementation in developing countries: a SWOT-AHP approach. Journal of Geographical Systems 11.3 .

[44].[Kepres]. (2001). Keputusan Presiden no 103 tahun 2001 Tentang Kedudukan, Tugas, Fungsi, Kewenangan, Susunan Organisasi, Dan Tata Kerja LPND. Jakarta

[45].[Perpres]. 1994. Peraturan Pemerintah Republik Indonesia nomor 21 tahun 1994 tentang penyelenggaraan pembangunan Keluarga sejahtera

[46].[UU] .(1992) Undang-Undang RI NO.10 tahun 1992. JID. Jakarta

[47.[-------. 2009. Undang-undang nomor 52 tahun 2009 tentang perkembangan kependudukan dan pembangunan keluarga 